\title{
Observations on the Prospects for a Private University Sector in Ontario*
}

\section{ROBERT M. PIKE**}

\begin{abstract}
Unlike the United States, the Canadian provinces have established public monopolies of degree-granting institutions to which there are few private exceptions. This paper offers a case-study of challenges to the public monopoly in university education in one province-Ontario. Recently, the Ontario Council on University Affairs has been hearing the opinions of a number of interest groups and private colleges which have challenged the regulations limiting broad degree-granting privileges to the existing publicly-funded universities and their affiliates. Following a brief historical account of the development of the public monopoly, the arguments of these proponents of private universities are reviewed and evaluated under the headings of their proposed benefits of "accessibility", "diversity" and "quality". It is concluded that, from a sociologist's perspective, the arguments for the establishment of private universities in the province are not strong. However, given the current emphasis on privatization, the pressure for private universities will probably continue to grow in all Canadian provinces. Thus, a recommendation is made for improvement of Ontario's current inadequate affiliation arrangements.
\end{abstract}

\section{Résumé}

Au contraire des États-Unis, les provinces canadiennes ont établi des monopoles publics d'institutions qui accordent des diplômes, auxquelles il y a peu d'exceptions privées. Ce rapport représente une étude de dossier des défis au monopole public en éducation universitaire dans une province-l'Ontario. Récemment, le Conseil des affaires universitaires de l'Ontario a entendu les opinions de plusieurs groupes intéressés et de collèges privés qui ont revendiqué les règlements limitant les pleins privilèges des universités actuelles financées par le public et de leurs filiales à accorder des diplômes. À la suite

* The author acknowledges the financial assistance of the Donner Foundation in supporting research related to this paper.

** Professor of Sociology, Queen's University, Kingston 
d'un bref rappel de l'évolution du monopole public, les arguments de ces défenseurs des universités privées sont révisés et évalués sociologiquement sous les rubriques des avantages proposés de "l'accessibilité", de "la diversité" et de "la qualité". L'auteur voit peu d'arguments sociologiques valables pour l'établissement des universités privées dans la province. Cependant, étant donné l'emphase actuelle sur la privatisation, la pression sur les universités privées va sans doute continuer à augmenter dans toutes les provinces canadiennes. Ainsi, on recommande une amélioration des arrangements insuffisants d'affiliation en Ontario.

\section{Introduction}

The concept of "privatization" is much in vogue at the present time. In countries such as Canada, Britain and the United States, it has been applied as a basis for policy decisions primarily to deregulation or the sale of public assets in various spheres of communications and transportation. Behind this trend appears to be a substantial suspicion of public and regulated monopolies which were established in earlier times to serve the public interest as traditionally conceived. Amongst these monopolies can be included public primary and secondary education which has dominated in most western countries for the past 150 years, although fee-paying private schools run by individuals and groups, and in some cases enjoying a measure of public funding, have usually tempered the monopoly. At the post-secondary level, however, in countries such as Canada where there is a virtual public monopoly of university education, privatization has only recently posed some limited challenges to that monopoly. More generally, James Perkins, the chairman of the International Council for Educational Development (New York) has identified an international trend towards privatization in the higher educational sphere as taking three forms: a more benign attitude towards the creation of new private institutions; an increased public interest in maintaining and improving the quality of existing private education; and strong efforts to increase the private support of public colleges and universities (1987: 1-2). To these can be added a fourth-the growing involvement of private corporations and proprietary schools in the provision of higher education and training to their employees and to others (see notably, Paquet, 1988).

According to Perkins, the growing interest in educational privatization is a result of restrictions on public funding for higher education and also because of disquiet over excessive bureaucratisation and partisanship in the administration of public universities and colleges (ibid.). To this, may be added the view of 
Anthony Smith, President of Magdalen College, Oxford, that the trend towards privatization and deregulation in many spheres of activity can be seen as a move from a faith in government intervention as the instrument of public benefit to a new faith in a revival of market forces and the interplay of individual motivation as a surer path to collective benefit (1989). Attacks on public and private monopolies are part of this trend, whether in higher education or telecommunications.

In the light of these developments, this paper includes an examination of one aspect of the trend towards privatization in higher education in one province: namely, recent developments related to the desire by some private institutions and groups to change the regulations pertaining to the establishment of new degree-granting institutions in Ontario. Following a brief historical review of the development of the public monopoly in university education in Ontario and the rest of Canada, the paper provides a brief examination of the Ontario government's policies on the establishment of new private universities. Subsequently, an outline is presented of the characteristics and arguments of the proponents of private universities, as contained in some of their recent briefs to the Ontario Council on University Affairs (OCUA) which is an advisory body to the minister of colleges and universities; and an examination is then made, predominantly from a sociological perspective, of the extent to which the development of a private university sector is likely to benefit, or otherwise, the public welfare of the province. Finally, some suggestions for changing the current policies on the establishment of new private universities are offered.

Although this paper is predominantly a case-study of one province, many of its findings and conclusions have evident relevance to the rest of Canada. Thus, Michael Skolnik has noted that the granting of the authority to award degrees in this country has been the prerogative of provincial legislatures which have stringently limited the number and diversity of degree-granting institutions (Skolnik, 1987, p. 67). By contrast, in the United States, no state authority is needed to grant degrees or such authority is granted by a licensing commission (Ibid.). It is true that Alberta has incorporated twenty-one private colleges under private acts of the Legislature, and an additional eighteen non-public, postsecondary institutions operating under other legislation (Alberta Private Colleges Accreditation Board, March 1990): all of which seems to contradict the strictness of provincial government control. However, whilst a number of these colleges offer degrees in theology and divinity, only three "accredited" private colleges (which are not allowed to use the name "university") have been accorded the direct privilege of awarding baccalaureate degrees in addition 
to the degree of divinity, and two of these retain affiliation ties with the University of Alberta. ${ }^{1}$ As another example, until 1989, Quebec had no restrictions on the use of the word "university" or the granting of a degree. However, in 1989, the provincial government passed Bill 128 which belatedly regulated which institutions can call themselves universities and advertise themselves as offering university-level studies. The Bill has left approximately 38 private institutions operating in the province in violation of the law, and ultimately subject to closure unless they obtain a charter from the Quebec legislature granted on the basis of stiff academic criteria (Desrosiers, 1989a and $1989 \mathrm{~b}$ ). The public monopoly of university education appears to have been reaffirmed in the province, since the general expectation is that the charter will not be easy to obtain. ${ }^{2}$

In the next section, we review some historical and contemporary features of the development of the public monopoly of degree-granting in Canada which are relevant to the issue of private universities. Michael Skolnik has examined many regulatory aspects of this issue in detail (1987), but the broader sociohistorical brush still needs to be applied.

\section{Some Historical and Contemporary Aspects of the Development of a Public Monopoly in Canadian University Education}

Until about forty years ago, many universities - most notably in central and eastern Canada-were largely privately-funded and often affiliated with a particular church. Canada has, therefore, a long experience with private universities. Ultimately, however, almost all of these institutions came to rely heavily on government financial support-in fact, "went public". They did so for good social and economic reasons which are worth outlining here, because these reasons have some bearing both on the attitudes of those who defend the present public systems as well as on the future prospects for the development of private university sectors.

The simplest answer as to why the private universities went public lies in the early impact of the all too common experience of the underfunding of Canadian institutions of higher education. Thus, the systems of Canadian university education which existed, circa 1930's to 1950's, were both academically and socially elitist, as well as starved of adequate resources. In the immediate postwar decades, therefore, the increasing intervention of the federal and provincial governments in university funding, accompanied by withdrawal of many 
universities from formal church affiliation in return for government support, was perceived to be a necessity in the face of the glaring contemporary need for expansion of the university systems. The alternative possibility-that private enterprise and philanthropic organisations, supplemented perhaps by increased tuition fees might provide the necessary extra resources-was, as historian Paul Axelrod has shown, not seriously considered to be possible, either by governments or private enterprise. As he notes, in the late 1950's, Canada-unlike the United States-found itself singularly disadvantaged in lacking large, richly-endowed private institutions capable of absorbing the mass of students arising from the baby-boom (1982, 35-36; 1986, 50). In accordance with Canadian traditions, therefore, the government was expected to intervene. "Whether the private sector has been uncommonly weak, as some theorists have recently argued, whether the historical desire of the Canadian people for government activity has been uncommonly strong, as others have surmised, or whether inspired by the endless problems of regional disparity and national unity, Canadian governments have played a vital role in buttressing, stimulating and establishing the free enterprise economy" (Axelrod, 1982, p.35).

To move forward in time, it can be suggested that the publicly-supported university systems which have emerged from the above developments have generally served the public well. Following the massive university expansion of the 1960's and early 1970's, provincial governments largely called a halt to the creation of new universities, but placed much emphasis on ensuring student accessibility to existing institutions both through controlling tuition fees at well below U.S. state university rates, ${ }^{3}$ and recently, in the case of Ontario at least, through "accessibility funding packages" which rewarded universities for increasing their student intake. In turn, the universities have responded by being collectively open enough and flexible enough to cater to a higher proportion of the related-age groups over a wider range of programmes than is evident in most other western educational countries except the United States. Unfortunately, however, on the flip side, heavy reliance on public funding has left Canadian universities extremely vulnerable to the vagaries of state economic policy - which, with variations in onset from one province to another, has been characterized by years of financial constraint. More specifically, continued pressure of student numbers combined with declining real financial resources is seen as threatening the capacity of the system both to maintain the quality of existing programmes and to launch new ones.

As Perkins noted, one outcome of restrictions on public funding has been strong efforts to increase private support for public colleges and universities. 
Thus, in Ontario and other provinces, many Canadian universities, which were once private, and changed their status when private resources proved inadequate to meet public needs, are again striving hard to increase funding from corporate and other private sources in order to make up some of the short-fall in government grants. However, as Muller and Sepehri have shown (1988), the tradition of private and notably corporate support for Canadian universities is still less well established, and more volatile, than in the United States. Canadian-based corporations are less likely to have well established sponsorship agendas than their American counterparts, with the result that Canadian universities find themselves competing with culture and the arts for uncertain, and fluctuating, levels of support (p. 176). These conditions inevitably cast some doubt on the prospective financial viability of private degree-granting institutions in this country-but more specifically, in Ontario where many existing universities are already in the competition for funds. They may also help, as we shall see, to explain the reluctance of existing universities and university organisations in the province to support the principle of private universities - that is, they fear the possibility of more competition for scarce resources.

\section{Ontario as a Case Study}

\section{Regulations Pertaining to the Establishment of Private Degree- Granting Institutions in Ontario}

At the time of writing (March, 1990), the Ontario Council on University Affairs is formulating recommendations, at the behest of the minister which, when submitted to the provincial government, might (or might not) lead to new public policy on the accreditation of private universities. ${ }^{4}$ Currently, in Ontario, privately-funded bible colleges and seminaries may obtain charters to award specialized or restricted degrees in religion, theology and related disciplines such as philosophy; but, unless they can affiliate with an existing university, public policy prohibits the organization of new privately-funded institutions offering conventional degrees in other disciplines (OCUA, 1989, p. 7). Indeed, the policy (known as the Roberts Policy) which was formulated during the early 1960 s, was based upon the belief that a sufficient number of provincially-assisted universities had been established to meet further foreseeable needs, and that no new universities, public or private, would be created. Any new institutions would have to affiliate with one of the fifteen established universities in order to qualify for provincial assistance and to permit their graduates to obtain degrees (OCCUA, 1989, p. 7). 
The present reconsideration of the Robarts Policy has been motivated by the request of a number of existing religious-based or commercial institutions for the right to grant secular degrees. Several other interested groups have indicated a wish to organize private secular-degree granting universities and have petitioned for a more permissive policy. A discussion paper outlining many of the main issues was prepared by OCUA in October 1989. The discussion paper refers to "the issue of the establishment of freestanding secular degree-granting institutions in Ontario" and asks the wider audience about the appropriateness of their establishment. By "secular" is meant all "non-theological, non-religious designated degrees" and by "freestanding" is meant "institutions established by an act of the Ontario legislature, which grant their own degrees, which do not receive any direct capital or operating grants from the province of Ontario and which are not affiliated with an Ontario university" (OCUA, 1989, p. 2). Interested parties were requested to submit briefs on the issue, and indeed this author did so. Some elements of the brief will be found in the later sections of this paper (Pike, December 1989).

Because many of Ontario's universities were originally private foundations, the Council of Ontario Universities (COU), the organization which represents the governing bodies of provincially-assisted universities, argues that these universities have kept their essential private character despite the "power of the purse" held by government. "Each university has its own charter and governing body. It is responsible for the conduct of its own affairs and has effective control over them. Each university determines what academic programmes it will offer, and the admission and degree requirements of these programmes. In short, each university has a high degree of institutional autonomy" (COU brief to OCUA, Jan. 26, 1989). Hence, the Ontario universities' preference for the use of the term "provincially-assisted" or "publicly-funded" universities rather than "public universities" to describe the existing universities of the province. This distinction seems slightly casuistic in light of the admission by COU that lack of adequate public funding and a high degree of control over other revenues means that the provincially-assisted universities are "not at the present time in a good position to respond to changing student demand and societal needs." However, it requires one to note that a public university is defined throughout the rest of this paper as one which depends mainly on public funding, though some private funds will usually be available. Likewise, a private university is defined in line with the OCUA document, although it is appreciated that a private university may receive public funds in the form of tuition fees covered by student aid, government research grants and contracts, etc. 
As a textual footnote to the above, it should be stressed that the policy of maintaining strict limits on the number of provincially-based degree granting institutions raises some difficult issues in the case of out-of-province (and usually foreign) institutions which offer degree-granting facilities to provincial residents. In Ontario, there are seven such institutions functioning at 21 locations under ministerial consents (OCUA, 1989, p. 80). ${ }^{5}$ Many of the issues relating to these institutions, including the evident inconsistency of permitting foreign institutions to award degrees to Ontario residents whilst prohibiting various indigenous institutions from so doing, are discussed in Skolnik (op. cit: 71-79) and will not be explored further at this point.

There follows now a brief description of the nature of those groups which seek to gain degree-granting status in Ontario, and the tenor of their main criticisms of existing arrangements. Their arguments outlining some of the purported benefits of private degree-granting institutions will be incorporated in the text at a later stage. Research on the theme has been assisted by access to some of the letters and briefs presented by these groups to OCUA about a year ago.The information from these briefs was supplemented by telephone interviews with two major supporters of two new proposed private universities which are only now at an early stage of development. ${ }^{6}$

\section{Proponents of Private Universities in Ontario: their Nature and their Arguments for General Degree-Granting Status}

The number of groups which appeared before the Freestanding Institutions Committee of OCUA in January of 1989 to express their viewpoints on the inadequacies of the Robarts Policy was not large-just 11 excluding COU which also made representations-but they were varied in nature and interests. An annotated list of these groups and, where relevant, related institutions may be found in Appendix A. However, during the intervening period, the proponents of a new secular private university to be called "Wolfe University" have divided into two groups. One of these groups, spearheaded by Dr. Bette Stephenson, the ex-minister of colleges and universities, has been given approval to establish a foundation - the East Gwillimbury Foundation for the Advancement of Post-Secondary Education - to raise money to create a private university on donated land in York region (Toronto Star, March 15, 1990). The other is incorporating as the Wolfe Consortium for Advanced Studies Inc. and has just held a founding convention. ${ }^{7}$. In both cases, there is an act of faith that the present restrictive legislation on private universities will ultimately be changed. 
Both of these bodies, and possibly Bayview Glen which is a private school wishing to extend its operations, have in mind the creation of intellectually elite private liberal arts colleges on the American model. Such colleges would have to be organised and financed from the roots up, as would a proposed International Study Centre in business, communications and technology which is supported by a number of major companies in Sarnia and Port Huron, Michigan, and would centre upon these cities (see letter of Sam D. Marble to OCUA, Oct. 26, 1988). However, a number of other institutional proponents of private universities already have the available organizational infrastructure. Three of these are religiously-based institutions (Redeemer College, the Institute for Christian Studies and Maimonides College for Jewish Studies), all of which are entitled to offer religious or theological degrees, but would like to offer "secular" degrees (albeit with a particular value perspective) either in affiliation with an existing university or independently. Another is a medical facility, the Canadian Memorial Chiropractic College which, failing affiliation with an existing university, wishes to obtain independent degree-granting status.

The remaining groups are somewhat of a "mixed bag": two private commercial institutes, the Canadian School of Management and Devry Institute of Technology which offer various certificates and diplomas and would presumably like to offer degrees (briefs outlining their position were not available); the travel organisation Blyth and Co., which operates the Université Canadienne en France in conjunction with Laurentian University, and Nipissing University College at North Bay which is affiliated with Laurentian but favours the chance of becoming a full degree-granting institution in its own right. Parenthetically, in late 1989, five of these institutions had formed themselves into the "Coalition of Free-Standing University-Level Institutions" which then included the proposed Wolfe University. ${ }^{8}$

\section{Their Criticisms of the Robarts Plan}

i. Persistence of a Public Monopoly. There was a strong view expressed by many of the proponents of private degree-granting institutions that the present arrangements in Ontario (as elsewhere in Canada) constitute a public monopoly which is based upon implicit academic arrogance, is in constraint of competition and limits institutional diversity. As noted by one of the primemovers behind Wolfe University, "we are confronting a monopoly and therefore we think the onus is more on the government to justify our exclusion from the practice of our academic trade in the traditional mode of a university as a guild 
or community of scholars of common persuasion" (letter of D.V.Anderson to chairman of OCUA, 24 Dec. 1988 ). Again, in the brief from Bayview Glen, it is noted that:

By permitting no alternative to the existing system, the [Robarts] policy essentially prevents the citizens of Ontario from exercising a perfectly valid choice. Further, although we are sure that the consequence was not intended, the policy implicitly implies an assumption (some would say an arrogant assumption) that only a university in the public sector can be relied upon to provide a higher education of quality, or safely be charged with the responsibility of monitoring the development of a new university. We know of no objective evidence that would justify such an assumption" (Bayview Glen brief, Jan.1989, p. 1).

However, not all existing private institutions were, as in the Bayview Glen case, clearly opposed both to the persistence of the public monopoly and the principle of affiliation. This became evident from the number which would have liked to affiliate with an existing university, but were frustrated by their inability to do so. Some examples are cited below.

ii. Failures of the Affiliation System. Affiliation has been a widely used policy in Canada, and many present universities were at one time affiliated institutions. Nipissing University College, being currently affiliated with Laurentian, was willing to recognise some of the system's benefits as an agency of quality control:

an affiliated college enjoys the academic guidance and tutelage of the larger university while retaining control of its own administration and financial affairs. Affiliation allows a small, newly-established college to teach courses which carry acceptable academic merit. The larger university benefits by receiving transfer students completing programmes not available at the affiliate in their entirety (Nipissing University College brief, 30 Jan. 1989)

On the other hand, such institutions as the Institute for Christian Studies (ICS) and the Canadian Memorial Chiropractic College (CMCC) were frustrated by their long-term failure to obtain an affiliation agreement with an existing university. The ICS noted that they would welcome affiliation for many reasons, but having unsuccessfully approached eight universities in 1974-76 and renewed the approach with four of them in 1980 , "our experience clearly 
demonstrates that affiliation has not been a viable option for us; frankly it has been a non-starter" (ICS brief, Jan.31, 1989, p. 2). Similarly, the brief of CMCC claimed that its failure to secure affiliation in Ontario had led to negotiations with the University of Victoria in the hope of obtaining affiliation there. The CMCC would move to British Columbia if it had to, so notes the brief, but with a major loss of jobs and also a $\$ 75$ million loss to the local community. Preferably, "if a fair and equitable system of affiliation that ensures the proposal is evaluated on the merits of the case, and which is not controlled by the universities, is not established, then private institutions should be given degree granting charters" (CMCC brief, Jan 31st, 1989).

There is no doubt that many Ontario universities do not look with much interest on the affiliation proposals of private colleges, particularly if they wish to offer liberal arts programmes which seem to duplicate those offered on the main campus or, as in the case of CMCC, teach "alternative health sciences". As the conclusions to this paper will emphasize, this is certainly a weakness of the present affiliation procedure which needs to be revised in favour of a more responsive and just arrangement. ${ }^{9}$

Finally, it should be mentioned that academic quality control was certainly on the minds of many of the supporters of private degree-granting institutions, and they offered various suggestions for ensuring the maintenance of academic standards in the eventuality that their briefs led to a favourable outcome. On a different tack, however, whilst some institutions (the CMCC, for example) suggested that private degree-granting institutions should have access to direct public funding, this sentiment was by no means universal. On the contrary, in many of the briefs and later telephone conversations, there was much emphasis on the need to maintain academic freedom through reliance on private sources of income, though public student aid and research funding were generally deemed acceptable. However, in contrast, the OCUA discussion paper notes that "most [private] institutions make it very clear that they want access to public funding" (1989, p. 57). Thus, it cannot can be readily assumed that access to direct public funding would be a non-issue for most private universities. Certainly, no such assumption is made in this paper.

\section{Possible Characteristics of a Private University Sector in Ontario}

In the light of the nature and concern's of groups seeking degree-granting status, what public benefits might be added by a series of private universities to the province of Ontario and to its students? This question can only be meaningfully 
answered on the basis of some prior speculation as to the probable characteristics of a private university sector if it were to be permitted to develop. Such speculations are just that-speculations based upon knowledge of likely outcomes. It is recognised also that in the light of the various kinds of groups and institutions seeking degree-granting status, there would not be an archetypical private university in Ontario. Some groups, as we have seen, hope to create secular universities on the U.S. liberal arts model. Others wish to build upon their "culturally distinctive" religious institutions. Still others seem to be aiming at the creation of degree-granting institutions with a strong professional or vocational orientation.

Even given these caveats, the following observations are still apposite. Overall, the number of private universities which would succeed in establishing themselves in Ontario would probably be few-the present demand, if any long-term indicator, does not seem very great and, although one supporter of the private sector claimed that "great amounts of private money were available", she also agreed that private giving by corporations and foundations to universities in Canada had been marked by parsimony (interview with $B$. Stephenson). Thus, whilst some of the religious institutions might be able to attract substantial funds from their faithful supporters, it is doubtful whether many (if any!) new private ventures such as the East Gwillimbury Foundation could be financed at a level required to provide adequate academic facilities and services. Hence, although Slaughter and Skolnik, in comparing Canadian and American university systems, note that "There is no private sector [in Canada] which can provide insulation from trends in public funding or pressure the public sector to keep up..."( 1987 , p. 129), it seems quite unlikely that a private sector in Ontario would be sufficiently large enough or influential enough to allow it to act as a competitive stimulant to greater efficiency or programme diversity in the public sector. Such competition has been claimed as one of the benefits of permitting private universities to develop in the province (Stephenson interview and Bayview Glen brief, p. 2).

The above comments are made on the assumption that private universities would be excluded from access to public operating and capital funding; an exclusion contained in their very definition in the OCUA discussion paper. Indeed, since Ontario has fallen well below nearly all other provinces in university operating grants per FTE student over the past decade (COU, Oct. 1987: fig.4), such an exclusion would be regretfully necessary in order to ensure that the existing universities do not suffer yet further in the increased competition for scarce resources. ${ }^{10}$ The result would be, of course, that most 
private institutions would have to charge high fees (some of the existing colleges already do by the standards of existing universities) ${ }^{11}$ in order to strive for an adequate income. In turn, it would be logical to assume that their clientele would tend to be drawn from those higher income families which could afford the fees. However, this being said, it must be recognised that the social composition of the student bodies of private degree-granting institutions is always much influenced by the availability of institution-based and public financial aid. Also, in the case of religious-based colleges, less well-off families might prove willing to pay high fees in order for their offspring to receive the appropriate spiritual and moral training. As the Institute for Christian Studies noted in a broader context, their supporters were "more frugal than the average Canadian" (ICS brief, p. 3).

The issue of the impact of potentially high tuition fees is worth exploring a little further here. Thus, the Ontario Council of University Faculty Associations (OCUFA) has condemned private universities in a newsletter editorial, partly on the grounds that "the potential exists for creating a university system for two classes of students (those who can afford to pay large sums of money and those who cannot)" (OCUFA Forum, Sept. 1989, p. 2). However, when the author mentioned to one of the prime movers behind the East Gwillimbury Foundation that high tuition fees might be associated with social elitism, her response was that the new university would aim to attract an intellectual elite, but it would not be a social elite because institution-based scholarship assistance would be provided for the meritorious (interview with Stephenson). The prospect of large sums of money being made available for such ends, in the context of Canadian private giving, seems a little doubtful-but here only time can tell. More certain, in accordance with a tentative regulatory principle suggested in the OCUA discussion paper, is the likelihood that students attending private universities in the province would be eligible for public financial aid, but only to the same extent as students attending publicly-funded universities (OCUA, 1989, p. 69). This principle would certainly give less well-off students a measure of financial freedom to attend one of these institutions if they so desired. However, based upon American experience, as outlined below, policies on public student aid to private institutions need to be planned with great care.

In the United States, an expert on private higher education, Roger Geiger, has noted an unprecedented rise in the fees of private universities since the early 1970 's with the tuition increases fed by increasing public needs-based financial aid. In turn, part of the tuition increases (about 20 percent) has been allocated by private universities and colleges to their own institutional student aid. Geiger 
calls this the "aid-tuition spiral" which has helped to fuel demand for private education, and to finance the private institutions, but which is leading to "dangerously high levels" of student indebtedness (1988, pp. 7-9). This is the kind of spiral which Ontario, or any other province permitting the establishment of private universities, should endeavour to avoid. Short of restricting all public student aid to the public university sector (which would indeed be discriminatory), the only solution might well be to stick rigidly to aid ceilings established for the public sector.

\section{The Prospective Benefits, or Otherwise, of Private Universities in Ontario}

Roger Geiger has noted that there are three "pure functions" of private sectors, one or more of which might justify their creation: supplying more higher education; supplying different higher education; and supplying higher education that is in some sense better than that available from the state (1986, p. 165). In the OCUA discussion paper, a series of arguments for and against private degree-granting institutions includes reviews of "accessibility," "diversity" and "quality" which are clearly linked to the above functions (OCUA, 1989). These three functions will now be critically reviewed, utilising the discussion paper's terms, but seeking to reach some conclusions--something which the discussion paper is, for the most part, scrupulous to avoid. The proponents of private universities have already been noted. The opponents include many of the existing universities, the Council of University Affairs in its brief to OCUA and, as noted, the Ontario Confederation of University Faculty Associations (OCUFA) in its newsletter. For example, the COU wishes to maintain present policies, a "judgment [which it claims] does not represent a monopolistic attitude on the part of institutions which currently possess the right to grant degrees and fear competition from new universities. It is based primarily on academic grounds" (COU brief, Jan. 26, 1989). For its part, OCUFA perceives private universities to constitute threats to academic quality, to academic freedom and equality. One of the major criticisms of the OCUFA against private universities is that a church related college might threaten academic freedom by requiring its academic staff be of a particular religion even to teach in areas where expertise in religious matters does not bear any evident relationship to the subject matter (OCUFA Forum, Sept. 1989, p. 2). Thus, St. Augustine's Seminary was disaffiliated from the University of Toronto in 1988 when its representatives refused to subscribe to the University's personnel policies and 
dismissal procedures which promote academic freedom. Quite clearly, however, such a problem could be resolved if all initial affiliation arrangements contained appropriate clauses guaranteeing academic freedom.

i) Accessibility. The issue of accessibility did not frequently appear in the briefs of the supporters of private degree-granting institutions received by OCUA. Nonetheless, the argument that the development of private universities would facilitate access to higher education for more students, and perhaps also take some of the enrolment pressures off the beleaguered public sector, is prima facie an attractive one. More generally, opportunities for access to university education can be defined: (a) in terms of the numbers of university places in toto available to qualified candidates; (b) the number of places available in particular institutions and programmes to those qualified candidates who apply to them; (c) the relative numbers of places taken up by members of different social classes and groups within the community. In terms of the first of these definitions, it is difficult to believe that private universities in Ontario (especially if their numbers remained small) would substantially increase accessibility when the present public system is, albeit with growing difficulty, already accommodating a substantial majority of qualified candidates. ${ }^{12}$ In terms of the second, it is possible that private universities offering degree programmes for which the demand is much higher than the supply of places in the public system might facilitate access to programmes of first choice for those students who can afford to pay for them; but presumably the augmented number of places would not be very large unless there was a burgeoning of private universities. (The issue of offering programmes not available in the public system is examined under "diversity" below).

In terms of the third definition of accessibility - participation from different social segments of the population - a strong case could be made for private universities if they were to offer opportunities for degrees to those groups who are now underrepresented in the public system-for example, lower income people, some disadvantaged ethnic minorities, and people from rural areas. However, in most instances, this is made unlikely by the probable high cost and/ or sectarian nature of such institutions. In cases where the private institution wishes to cater to the communal interests of a particular ethnic or religious group (e.g. Maimonides College) the issue of accessibility, as defined, would only be relevant if it could be shown that the members of that group were excluded or seriously underrepresented in the public university system. There is no evidence that such is currently the case. ${ }^{13}$ 
In general, therefore, the argument that private universities in Ontario would facilitate accessibility is not very convincing. This conclusion is, however, based upon the assumption that admission standards to such institutions, and the quality of their programmes, would at least match those of the public sector. As Roger Geiger has shown, mass private university systems such as exist in the Philippines, Brazil and in Japan (within the latter's less prestigious institutions), can be used to provide a large volume of education of low average standards (Geiger, 1986, notably chap. 2). Again, as U.S. experience has shown, it is quite possible to increase access to degrees by establishing second-rate private universities and, worse still, diploma mills (Stewart and Spille, 1988). Certainly, the supporters of private universities in Ontario would not themselves favour any such development.

ii) Diversity in University Education. Slaughter and Skolnik have noted that diversity of institutional role and mission has been a hallmark of American higher education, whilst, contrariwise, Canadian university systems and institutions tend to be quite homogeneous with respect to mission and standards, with resources for graduate studies and R\&D being quite dispersed (1987, p. 130; see also Skolnik, 1986). Such inter-institutional homogeneity is associated with less evident differences in institutional status and prestige than are apparent in many other countries: and, insofar as the higher rungs of institutional prestige hierarchies-for example, the American Ivy League schools-become agents for the maintenance of inequality and social stratification in the wider society, this inter-institutional homogeneity may be considered a positive feature of university education in Ontario and the other provinces. On the other hand, there is little doubt that privately-funded universities do have the potential to offer a diversity of academic programmes, teaching methods and world-views and could offer access to a range of educational alternatives which are not currently available, both as a result of funding policies and economic constraint, in the public system. Thus, provided that academic freedom and openness in personnel matters are adhered to, ${ }^{14}$ supplying different and diverse higher education seems to be one of the strong elements of the case for a private sector.

In their briefs to OCUA, the religious colleges strongly emphasized their value as educational alternatives to the public system in order to meet the cultural and educational needs of various religious and ethnic groups and for those people who wished for a higher education which was not ethically neutral. For example, the acting president of Maimonides College in a letter to OCUA (30 Jan, 1989) noted: 
I would like to affirm the need for private universities for Christian, Jewish, Muslim, Hindu, Buddhist, Inuit and Native Indian communities in Canada, in order to provide an academic focus for the development of their religious traditions and cultural heritage... A rich mosaic of a multicultural Canada would surely be enhanced by the presence of independent religiously affiliated universities.

Similarly, the Institute for Christian Studies noted that there was a lot of talk about society's need for citizens with a highly developed sense of personal values, including preeminently a set of moral values:

This particular aspect of societal need is often central to the reasons why the private institution was established in the first place; it is often a major part of its raison d'être. Is it too much to suggest then, that many private institutions almost inevitably may be expected to make a distinctive and valuable contribution to this particular fact of societal need? ( ICS brief: 4-5)

And finally, though the spokespersons for the East Gwillimbury Foundation and the Wolfe Consortium for Advanced Studies did not stress the value of religion per se, they did suggest that their proposed universities would offer programmes with a strong ethical framework, and notably a concern for the environment. Thus, the spokesperson for East Gwillimbury said that there was strong support for a total integration of the sciences and the humanities-the need, for example, for the kind of integrated programmes which would create engineers with a strong consciousness of environmental issues. In her view, public universities were not likely to institute such programmes, though there was no reason in principle why they should not do so.

Since many universities in Ontario and elsewhere began as religiously-based institutions, and since Ontario permits private primary and secondary schools of various denominations to function in the province (although without public funding), the above arguments are somewhat difficult to criticize on logical grounds. Nonetheless, a case can also be made for government policies, particularly in the area of funding, which encouraged a greater measure of institutional variety, and of programme choice and experimentation, within the public system, rather than policies which favoured the creation of separate private degree-granting institutions. Some arguments in favour of this case involve: first, the view that universities which offer degrees in accordance with a particular religious or ethnic world-view are meeting a valuable social need is debatable (and especially if on the multi-pluralist scale suggested by the acting president of Maimonides College). This is because universities can be 
considered as agencies for regional, and possibly, national integration and understanding rather than for the reinforcement of particularistic values and beliefs. ${ }^{15}$ Admittedly though, it is not likely that a few such universities would undermine the vital elements of our common cultural identity in Ontario or in Canada as a whole. Concern should, therefore, be focussed rather on a second matter-as already mentioned, the linkage between private higher education and social stratification.

It has been noted that the publicly-assisted universities in Ontario, and elsewhere in Canada, show less evident differences in institutional status and prestige than are apparent in many other countries, including the United States. Of course, such differences are not entirely absent amongst Ontario universities, but they are not reinforced by the existence of a substantial private sector which, as American sociologist Martin Trow has argued, contributes to "the American interest in, indeed almost an obsession with, relative prestige rankings amongst universities [and] arises out of the unique importance of private universities in the United States...the large majority of the more prestigious universities are private institutions, as is (sic) also four year colleges" (Trow, 1987, pp. 134-135). Trow goes on to note that this phenomenon is linked to private universities' dependence upon several markets in which they compete for high quality students, for distinguished teachers and researchers, for research support and for scholarly research publications and honours (Trow, 1987). Hence, although it is not likely that a private secular university in Ontario would be able to attract, relative to scale, the lavish financial resources and elite clienteles of American top private universities, it should be recognized that prestigious private universities, like exclusive private secondary schools, can become central institutions for the education and intergenerational continuity of dominant social elites. This prospect-remote it might seem at present in Ontario-is of some concern to the sociologist interested in issues of educational equality. The gains in academic diversity from permitting the establishment of private universities have to be weighed against this possible addition to the arsenal of class privilege in the province. ${ }^{16}$

iii) A Better Quality Education? The OCUA discussion paper notes that "in most cases proponents of freestanding [private] institutions insisted that higher education of comparable or higher quality to that offered by the publiclyassisted system was their goal" (OCUA, 1989, p. 34). Certainly, as the American example suggests, one can find prestigious, affluent private institutions in that country which outrank the state sector universities on many 
criteria of academic quality in teaching and research. ${ }^{17}$ But as noted, it is also possible to find many marginal private universities and colleges of mediocre quality and poor reputation. As a gross generalization, one may suggest that in jurisdictions where the public university sector is dominant, a peripheral private sector is only likely to prosper if it can find a special academic niche for itself which the public sector does not wish to fill (the development of the vocationally-oriented grandes écoles in France is a case in point). Otherwise, there is likely to be little academic support for private higher education and a weak tradition of private and alumni gift-giving. For example, Britain's only private university, the University of Buckingham, has been cited by Roger Geiger as an illustration of the formidable entry problem posed by challenge to the hegemony of existing institutions (1986, p. 141), and its subsequent longterm undercapitalization has given the University a somewhat tentative and provisional character (Geiger, 1986, chap. 4; Shaw and Blaug, 1988).

There is a stronger tradition of corporate and alumni donations to higher education in Canada than in, for example, Britain or Australia (which is a country with a dominant public sector where some private universities have recently developed) (Geiger, 1988). Nonetheless, as noted, the state felt obliged to step in during the 1950's and 1960's to ensure adequate funding for the expanding higher educational systems. Also it was suggested earlier that patterns of private support for higher education in this country, and especially in the context of Ontario higher education, do not make the prospects for funding private universities seem very favourable. In these circumstances, although one cannot discount the possible success of a new private university in developing high quality and innovative programmes with the lavish backing of corporations, or special interest groups, it is more likely, as already noted, that financial difficulties-with the inevitable negative impact on facilities and resources-would be a more common experience of private universities in the province.

For such reasons, it seems less likely that most private universities in Ontario would be able to match or surpass the public sector in the quality of their resources and programmes than that they would be in a constant struggle for financial survival. The danger of permitting the establishment of ultimately second-rate private universities would, therefore, be very real, although this is a danger which is not currently evident in the relatively high-quality faculty and facilities of many of the institutions which are currently hoping to achieve degree-granting status. ${ }^{18}$ Rather, it is a potential threat for the future, especially since, as the COU argues, the Ontario government's decision about the criteria to be met by "offshore" [mostly American] universities operating in Ontario 
does not inspire confidence that high standards of indigenous private universities would be required (COU brief, p. 3).

\section{Summary of the Foregoing Discussion and Some Conclusions}

This paper has presented a review of the Ontario government's policy on the establishment of private universities, and an examination of some of the characteristics and arguments of those groups and institutions which oppose the public monopoly of university education in the province, and which seek to acquire direct degree-granting status. It has been shown also that there is opposition to the establishment of freestanding private universities from many existing universities and university organisations on a variety of grounds. In the latter part of this paper, some support is given to this opposition, notably by emphasis on two sets of arguments. The first is that, lacking public funding, a future private university sector is likely to be small-scale, peripheral to the public sector, with many new private universities charging high fees-yet still finding themselves short of the required funds to meet the goals of a quality education. They are not, therefore, likely to make a major contribution to student accessibility in the province, although it is recognised that they may make some positive contribution to the diversification of educational programmes and the provision of educational alternatives. Ultimately, they are likely to seek public operating and capital funding, and thereby compete directly for resources with the public university sector.

Secondly, notwithstanding the above observations, there is a possibility that some private universities may succeed in attracting substantial financial support from wealthy special interest or corporate groups. These universities can be expected to function efficiently without public funding, and to offer a quality education. Although a certain concern has been expressed in the paper about the particularist role of universities which are run in the interests of specific religious or ethnic groups, a greater concern, writing from a sociological perspective, is that successful private universities tend to become mechanisms for the maintenance and transmission of elite social status.

In the light of these arguments, it would be preferable if the public universities of Ontario were assured of sufficient public financial support, and sufficient independence of action, to allow them much greater scope for more diverse and innovative programming - one area in which the supporters of private universities seem to be able to make a significant case (and especially when the case is removed from a particular religious context). For example, if implemented, the steps suggested in the Queen's University document Ontario's 
Universities: A Blueprint for Action (1989) would be a valuable means to this end, their purpose being to create a partnership between universities, government, students and the private sector in the improved funding of the university system during the 1990's-and hence, improved scope for programming. ${ }^{19}$ However, since there is also little evidence that a more generous funding spirit will prevail in the halls of government-and recalling Anthony Smith's observation that privatization constitutes a new conception of the public welfare in terms of individual and market interests as against monopoly control-it would be naive to believe that demands for the accreditation of private degree-granting institutions will fade away (especially since, as Gilles Paquet has noted, the expansion of efficient and effective training and development through "alternative providers" - notably private corporations - has been occurring at an unprecedented scale throughout the 1980's) (Paquet, 1988, p. 12). Hence, the stand of organizations such as the COU and OCUFA for the status quo is, if understandable, probably not realistic.

The best compromise solution to this problem in Ontario may be to achieve a more credible system of affiliation rather than to offer direct degree-granting accreditation to private institutions. Quite clearly, the present system of affiliation is inadequate because it provides no clear set of procedures and gives no cause for a public university to explain why a proposed affiliation has been rejected. Hence, in the author's brief to OCUA, a proposal is made for a more realistic affiliation process which included the establishment of a body within OCUA, somewhat equivalent to the Alberta Private Colleges Accreditation Board, which would have the function of overseeing and regulating affiliation procedures. The details of these proposals will not be given here, except to note that they would provide for a substantial "testing and evaluation" period during which time the private institution's claims to academic respectability could be readily evaluated. Ultimately, an affiliated institution would have the opportunity, after appropriate evaluations, of becoming a fully-fledged private university awarding a range of degrees. It would not, however, be eligible for public operating or capital grant support. ${ }^{20}$

Ultimately, all provinces may well find it necessary to create formal procedures, outside of acts of the legislature, to deal with the accreditation of private institutions which are seeking degree-granting privileges. Unfortunately, however, it is unlikely that any government of Ontario-new or immediate past - would be quickly moved to act by reference to the kinds of arguments pertaining to academic standards, access, and diversity which have been utilised in this paper. Conversely, however, they may be led to avoid action because of 
purely "political" considerations in which prospective costs will loom large. Since Ontario's universities like to consider themselves publicly-assisted but essentially private, the prospect of the creation of additional institutions which are private but might soon strenuously seek some public funding (and use political clout to get it, irrespective of any contrary regulations on the matter) is not likely to appeal to an economy-minded regime. Probably, therefore, there will be no drastic change in the Robarts Policy. If this assumption is correct, the public monopoly will remain intact, at least for the moment.

\section{Appendix A}

Groups which appeared before the Ontario Council on University Affairs (Freestanding Institutions Committee) on the Issue of the Establishment of Freestanding Secular Degree-Granting Institutions in Ontario, January 1989

Bayview Glen

Blyth and Company

Canadian School of Management

Canadian Memorial Chiropractic College

Council of Ontario Universities

Devry Institute of Technology

Institute for Christian Studies

Mr. Sam Marble and Mr. John Rozema for International Study Centre

Maimonides College

Nipissing College

Redeemer College

Wolfe University

Source: OCUA Discussion Paper: 81.

\section{Footnotes}

1 The three colleges are Camrose Lutheran University College, Concordia College and The King's College. The latter two retain affiliation ties with the University of Alberta. The province also contains two other "affiliated "private colleges which have an affiliation agreement with an Alberta university, but without the privilege of awarding their own degrees, and one "federated" private college which is affiliated with a university and academically integrated with it (See Alberta Private Colleges Accreditation Board, March 1990: 4-5).

2 The Quebec legislation states that no one, other than a listed number of provincial universities and écoles polytechniques or institutions established elsewhere in Canada 
which obtain an order-in-council, can call themselves a university, confer a degree, diploma or certificate or make other attestations of offering university-level studies unless they have degree-granting powers granted to them by an act of the Quebec legislature. This includes all universities established in any other country outside Canada, even the United States. The process of obtaining a charter from the Quebec legislature will be very complex, and expected to take between 1 to 3 years (Ontario Council on University Affairs, 1989, pp. 97-98).

3 The most detailed analysis of tuition fees in Ontario and elsewhere is David Stager (1989).

4 This statement was written before the success of the New Democratic Party at the recent provincial election. However, as the conclusions to this paper suggest, neither the immediate past nor present government is likely to act speedily to allow the accreditation of private universities-indeed, the NDP is likely to be more hesitant than the Liberals.

5 The most unique of these institutions is probably the GMI Engineering and Management Institute which offers a MSc in Manufacturing Management to GM employees on GM premises at Ingersoll, Windsor and Oshawa. Central Michigan University offers an M.A. in Education, Concentration in Community College Education, on four community college campuses in the province. Niagara University offers an M.A. in Education and an MSc in Education at nine locations. Other out-ofprovince institutions awarding degrees by ministerial consent are the Alfred Alder Institute of Chicago; the Free University of Amsterdam; Northern Illinois University; International Correspondence Institute of Missouri (Source:OCUA, 1989: 80).

6 Those interviewed were Dr. Bette Stephenson for the East Gwillimbury Foundation for the Advancement of Post-Secondary Education and Dr. D.V. Anderson for the Wolfe Consortium for Advanced Studies, Inc.

${ }^{7}$ Names for these prospective universities have not yet been chosen, although a good guess would be Simcoe University and Wolfe University respectively. As Dr. Bette Stephenson reminded the author, "Gwillim" was the maiden name of Elizabeth Simcoe; and presumably the origin of the name of the region of East Gwillimbury where a 100 acre site for the university has been donated by a development consortium.

8 The five institutions were Wolfe University; Canadian School of Management; Institute for Christian Studies; Canadian Memorial Chiropractic College; and Redeemer College (OCUA, 1989 p. 81).

${ }^{9}$ The problems of the affiliation system are outlined in the OCUA discussion paper in some detail. As noted there, "only one affiliation agreement has been reached in the recent past involving Brock University which accepted Concordia Lutheran Seminary as an affiliate in 1982. Five institutions participating in the [OCUA] 1989 public hearings indicated that they had attempted to affiliate, but without success (OCUA, 1989, pp. 1718). 
10 In view of the small number of private universities which would probably come into existence if new regulations permitted their establishment, the existing universities and university organizations may somewhat exaggerate their fear of a resultant fierce competition for resources in the same way that some proponents of private universities stress the benefits of competition. On the other hand, when resources are very tight, the arguments for spreading the available resources over more institutions are not easy to justify.

11 For example, the annual tuition fees of the Canadian Memorial Chiropractic College in $1988-89$ were $\$ 6,600$ for Canadians and $\$ 8,800$ for others. Tuition fees at the Devry Institute of Technology in 1988 were $\$ 13,585$ for seven trimesters of 15 weeks (105 weeks of school) in order to obtain an Electronic Engineering Technician's Diploma. To obtain a Computer Information Systems Diploma took 120 weeks for a total tuition fee of $\$ 17,355$ (Source: Calendars of respective institutions).

12 In 1988, the Ontario universities were registering in full-time programmes, about 66 percent of those active applicants who had been registered in 1987-88 in year 5 of an Ontario high school. Another unknown proportion would have enrolled on a part-time basis. However, the proportion of active applicants in other categories who subsequently registered full-time was lower-27 percent. (COU, Oct. 1989, notably table 10).

13 One has in mind. for example, the development of a degree granting institution which would have some of the characteristics of the Institute for Canadian Indian Arts or the Maskwachees Cultural College which are private colleges catering to the cultural and educational needs of Indian populations in Alberta. However, neither of these colleges grant degrees, although the former does have plans for post-secondary studies. There is little evidence in Ontario, however, of the development of private institutions intended to facilitate university level studies for disadvantaged groups.

14 One of the major criticisms of the Ontario Council of University Faculty Associations against private universities is that a church related college might threaten academic freedom by requiring that academic staff be of a particular religion even to teach in areas where expertise in religious matters does not bear any evident relationship to the subject matter (OCUFA Forum, Sept. 1989, p. 2). Thus, St Augustine's Seminary was disaffiliated from the University of Toronto in 1988 when its representatives refused to subscribe to the University's personnel policies and dismissal procedures which promote academic freedom. Quite clearly, however, such a problem could be resolved if all initial affiliation arrangements contained appropriate clauses guaranteeing academic freedom.

15 Michael Skolnik notes that one of the most contentious arguments in favour of diversity, relating to the matching of student and institutional characteristics, pertains to the maintenance of distinct subcultures in a pluralistic society. Those who favour such matching argue that sponsoring a college helps to perpetuate a distinct subculture and to give it legitimacy in the larger society ( e.g. Maimonides College). Those who oppose, 
are those who believe that higher education " should play an essentially homogenizing role in society" (Skolnik, 1986, p. 20). However, there is some emotional loading to the word "homogenizing"; rather, an "integrating" role might be better.

16 Clearly, one is referring here to the new ventures which have been proposed, and to any similar ones which could follow, rather than to existing institutions seeking degreegranting privileges such as the Institute for Christian Studies or the Canadian Memorial Chiropractic College. One could hardly support an argument that the latter would be likely to become an elite institution!

17 As Roger Geiger notes, the great American private research universities are unique in the extent to which they offer superior educational quality. The top research universities in the USA are private, they have much more select student bodies and the sheer quantity of resources available to them on a per-student basis is extraordinarily large (1986, p. 166).

18 For example, the Institute for Christian Studies employs 8 full-time faculty, all possessing doctorates, and 12 adjuncts, all with doctorates. Its students have access to the University of Toronto library system as well as an institutional library of 25000 volumes. At Redeemer College, of 34 faculty, 25 hold doctorates, 4 are completing doctorates, 2 have two master's degrees and 3 have a single master's degree. Redeemer's library contains 110,000 bibliographical items (Source: information supplied to OCUA).

19 The Queen's document calls for tuition increases of about $\$ 125$ per student for each of five years to compensate for a 30 percent decline in tuitions fees per FTE enrolment since 1972. This annual increase would be matched by government funding increases of an additional $\$ 375$ per student for each of five years, excluding normal increases related to inflation. No students would pay more than an additional $\$ 125$ during the course of their programme, and between 30-40 percent of the increased revenues from tuition would be used to bolster existing student assistance and student service programmes. These proposals would boost revenue without a major negative impact on accessibility. They have received substantial support from university organizations, but little evidence of action from the Ontario government.

20 The issue of whether or not private institutions should receive some public funding during the period of affiliation, as many now do, is clearly a sensitive one. Probably a measure of public funding should flow to the host university as an encouragement to affiliation in appropriate circumstances. It would be up to the host university to negotiate with the affiliate on the distribution of the funds.

\section{References}

Alberta Private Colleges Accreditation Board. (March 1990) Private and independent colleges in Alberta, third edition. Edmonton: P.C.A.B.

Axelrod, P. (1986). "Service or captivity?" Business-university relations in the twentieth century. In W.A.W. Neilson and C. Gaffield (eds.),Universities in crisis: A medieval 
institution in the twenty-first century. Montreal: The Institute for Research on Public Policy.

Axelrod, P. (1982). Scholars and dollars: Politics, economics and the universities of Ontario 1945-1980. Toronto: University of Toronto Press.

Bayview Glen School. (Jan. 1989). Brief to the free-standing institutions committee of the Ontario Council on University Affairs. Toronto: Bayview Glen.

Canadian Memorial Chiropractic College. (Jan. 1989). Brief to the free-standing institutions committee of the Ontario Council on University Affairs. Toronto: CMCC.

Council of Ontario Universities. (Oct. 1987). Ontario university financial requirements for 1988-89, Briefing Notes, No. 30. Toronto: COU.

Council of Ontario Universities. (Jan. 1989). A brief to the Ontario Council on University Affairs concerning private universities on behalf of the Council of Ontario Universities. Toronto: COU.

Council of Ontario Universities. (Oct 1989). Application statistics, 1988. Toronto: COU.

Desrosiers, J.Y. (Dec. 1988). État de situation préliminaire sur les organismes opérant ou désirant opérer au Québec en se faisant connaître comme dispensant des activités de niveau universitaire, postuniversitaire ou non traditionelles. Document de Travail, Direction Génerale de L'Enseignment et de la Recherche Universitaire. Québec: DGERU.

Desrosiers, J.Y. (Juin 1989). Project de Loi 128. Loi sur les établissements d'enseignement de niveau universitaire: Information sommaire sur des cas d'établissements revendiquant ou prétendant avoir un statut universitaire ou l'équivalent.. Direction Génerale de l'Enseignment et de la Recherche Universitaire. Quebec: DGERU.

Geiger, R.L. (1986). Private sectors in higher education. Ann Arbor: University of Michigan Press.

Geiger, R.L. (1988). Private higher education: Public policy and the competition issue. Conference draft prepared for the independent sector, Spring Research Forum, March 17-18, 1988: San Francisco.

Geiger, R.L. (1988). Privatization of higher education: International trends and issues. Princeton: International Council for Educational Development Confererce Report.

Institute for Christian Studies. (Jan. 1989). Institutional survey and presentation to the free-standing institutions committee of the Ontario Council on University Affairs. Toronto: ICS.

Maimonides College (Jan. 1989). Letter from C.E. Billigheimer, Acting President to the Ontario Council on University Affairs.

Marble, S.D. (Oct. 1988). Letter and preliminary proposal for International Study Center to Ontario Council on University Affairs.

Miller, T.E. and V.A. Sepehri. (1988). Corporate support for higher education: Trends in Canada and the United States. Research in Higher Education, 28 (2).

Nipissing University College.' (Jan.1989). Brief to the free-standing institutions committee of the Ontario Council on University Affairs. North Bay: NUC.

Ontario Council on University Affairs. (Oct. 1989). A discussion paper on the issue of the establishment of free-standing secular degree-granting institutions in Ontario. Institutional Policy Committee. Toronto: OCUA. 
Ontario Confederation of University Faculty Associations. (Sept. 1989). Private universities don't merit public support. Forum, $\underline{16}$ (14).

Paquet, G. (Nov. 1988). Training and development: The shadow higher education system in Canada. A paper prepared for the Canada/UK Colloquium on Post Secondary Education. Mississauga.

Perkins, J. (Nov. 1987). Privatization. In ICED Newsletter, New Jersey: Princeton.

Pike, R.M. (Dec. 1989). A brief to the Ontario Council of University Affairs respecting the establishment of free-standing secular degree-granting institutions in Ontario. Kingston: Queen's University.

Queen's University. (March 1989). Ontario's universities: A blueprint for action. Kingston: Queen's University.

Redeemer College. ( Jan. 1989). Presentation to the free-standing institutions committee of the Ontario Council on University Affairs re: general policy on free-standing. degree-granting institutions. Ancaster: Redeemer College.

Shaw, G.K. and M. Blaug. (1988). The University of Buckingham after ten years-A tentative evaluation. Higher Education Quarterly, 42 (1).

Skolnik, M.L. (1986). Diversity in higher education: The Canadian case. Higher Education in Europe, 2(2).

Skolnik, M.L. (1987). State control of degree granting: The establishment of a public monopoly in Canada. In Watson, C. (ed.), Government and higher education: The legitimacy of intervention.. Toronto: The Ontario Institute for Studies in Education.

Slaughter, S. and M.L. Skolnik (1987), Continued efforts to cope with declining resources: Selected post-secondary systems in the United States and Canada, an introductory essay. Higher Education, $\underline{16}$ (2).

Smith, A. (1989). The public interest, InterMedia, 17 (2).

Stager, D.A. (1989). Focus on fees: Alternative policies for university fees. Toronto: Council of Ontario Universities.

Stewart, D.W. and H.A. Spiller. (1988). Diploma mills: Degrees of fraud. New York: American Council on Education and Macmillan Publishing Company.

Trow, M. (1987). The analysis of status. In Burton R. Clark (ed.), Perspectives on higher education: Eight disciplinary and comparative views. Berkeley: University of California Press.

UTOR Development Group in care of Dr. D.V. Anderson (Dec.1988). Letter to the Chairman of the Ontario Council on University Affairs; and Response (Dec. 1988) prepared by D.V. Anderson for hearing of Ontario Council on University Affairs of 31 Jan. 1989. 